\title{
Technology, Relationship and Support Institutions on Sectoral Systems of Innovation and Production in Brazil's Northwest Bio Ethanol and Sugar Agro-industry
}

\author{
Francisco José Peixoto Rosário', Luciana Peixoto Santa Rita², Paula Pradines de Albuquerque³
}

\begin{abstract}
This study focuses on the interactions between economic agents, verifying the assumption that innovation and competitiveness in an industry are systemic, with relatively diffuse sources, which co-evolve. In this sense, were used the approach of the Sectoral Innovation System defined by Malerba (2002), analyzing the relationship between three dimensions of analysis: organizations, institutions and technologies. The object of this study was the Industry of Sugar and Ethanol in Alagoas, the largest producer and exporter of sugar and ethanol in the Northeast of Brazil. The results indicated a positive interaction between those three dimensions of analysis; show that there is interaction between universities and research centers, and much of the technological advancement comes from public and private partnerships. It is noteworthy that the research effort focuses on genetic improvement and on innovations of process. Thus, the study indicates that there is an innovation system locally circumscribed.
\end{abstract}

Keywords: system of innovation; innovation; industry of sugar and ethanol. 


\section{Introduction}

Brazil is known for its energy matrix which is based on renewable sources, particularly due to a successful program launched in the 1980s which managed to partly replace the consumption of fossil oils by sugarcane ethanol. The $\mathrm{Na}$ tional Alcohol Program (PROÁLCOOL) was the result of an efforts made by the Brazilian government and the sugarcane sector to build a market for a new fuel, on one hand, and to structure a nationwide production and supply network, on the other one.

However, by the end of the 1980 the state guardianship model showed some exhaustion signs and in 1990 the main sector regulator, the Institute of Sugar and Alcohol (IAA), was defunct by the government, which during the $90 \mathrm{~s}$ has gradually removed its protectionism from the sector. One of the main consequences was an extensive productive restructuring that occurred in that agro-industry.

During the 2000s the whole Brazilian sugar-energy agroindustry became the object of global observation, the industry holds for ethanol which is a renewable energy source as well as, most recently, for "bagaço", an emerging source of electric energy and finally for cellulosic ethanol (or 2 nd generation ethanol).

These clashes in technological environment and regulatory institutions led the Brazilian sugarcane agro-industry to a dominant level of production processes, distribution of fuel and sugar in a large scale and, as well, presented an advanced network of R\&D that has maintained the sector's development and competitiveness, since the birth of the National Alcohol Program (PROALCOOL) in 1974.

This agroindustry in Brazil is located in two distinct regions, which can be analyzed as two geographically separated subsystems of production. One subsystem of production is located in the South-Central Regions (Central-East, Southeast and South) and another is located in the North-East Region. The focus of this work is on the second subsystem, specifically the industry in the state of Alagoas.

After this reformulation, with the construction of new patterns of sectoral competition, new interactions between organizations have been generated and, especially, changed the governance structures of established firms and organizations.

Due to these changes, the Brazilian sugarcane sector, with its own modern technologies, became one of the most competitive in the world, presenting high levels of productivity, efficiency and lower production costs.
In this discussion, it is relevant mentioning the fact that in the Northeast region the sugar-energy agro-industry is representative, regarding employment and the gross value of production, particularly in Alagoas. In this state, the industry is responsible for $60 \%$ of the value of industrial transformation, employing $83 \%$ of all employed workforce in the state (Federação das Indústrias do Estado de Alagoas [FIEA], $20 \mathrm{IO}$ ) and $80 \%$ of state exports (Franco, 20II).This sectoral performance demonstrates the importance of this industry to the local development, justifying this study, mainly to emphasize the reference to the interactions between organizations, technologies and institutions within the local environment of innovation.

In this perspective, this study aims to discuss the research question: interactions between agents embedded in the sugar-energy agro-industry of Alagoas allow to frame this industry in a Sectoral Innovation System, as proposed by Malerba $(2002,2005)$.

To define and deepen this reflection, this article aims to analyze the interactions and technological articulations between firms in the sugar-energy industry in the state of Alagoas through the three dimensions of analysis (organizations, technologies and institutions), proposed by Malerba $(2002,2005)$. Specifically, the research described in this paper aims to assess the profile of sugarcane firms, the types of interactions between the firms and their competitors, as well as to measure the intensity and evolution of the interactions between the production units and their suppliers and other organizations. Additionally this article, pretend to verify rather it is possible to identify the dimensions (organizations, institutions and technologies) of a sectoral innovation system and how those dimensions jointly participate in the dynamics of this sector in the state, mapping the agents linked to the generation and diffusion of innovation.

According to these statements, the purpose of this article is supported in five sections. The introduction proceeds an approach to the problem, presenting the topic, the rationale and objectives of this article. Section 2 presents the conceptual foundations on the subject. Subsequently, section 3 presents the description methodological procedures. The results are presented in section 4. Finally, Section 5 presents the concluding remarks of the study and the bibliographic references.

\section{Analytical Framework: Sectoral Innovation System}

The theoretical literature about the Innovation Systems approach leads to the notion that the nature of innovation and production is systemic, understanding the firm an analytic unit, but unable to drive the whole process by itself; possible condition while inserted into a myriad of collabora-

ISSN: 07 I8-2724. (http://www.jotmi.org)

Journal of Technology Management \& Innovation (c) Universidad Alberto Hurtado, Facultad de Economía y Negocios. 
tive forms and interdependence with other organizations (Edquist, 2005, Malerba, 2002, Breschi \& Malerba, 1997). These organization may be other firms, suppliers, consumers, competitors, etc, or entities that do not act directly in the market, such as universities, government agencies, nongovernmental organizations, among others (Edquist, 2005).

The idea of Innovation Systems - IS - was a priori discussed in the 1980s, and was a part of analytical perspectives to important organs such as the Organization for Economic Cooperation and Development - OECD, European Commission and the United Nations Conference of Trade and Development - UNCTAD (Lundval et al, 2002).

By its systemic nature, the approach to innovation system puts focus on the innovation and the learning process. However, these central elements are, according to Edquist (2005), the result of a set of interactions between organizations, individuals agents and institutions that stimulate or mitigate the process of development, diffusion and the use of innovation.

Thus, according to this view, an Innovation System aims to explain the relationship between different types of institutions which jointly and individually contribute to the development and transmission of information and technology besides being an alternative for firms to acquire new skills and competencies.

Innovation systems can be defined nationally - National Innovation Systems - NIS, as well as in other levels of coverage, depending on the problem being studied (Edquist, 2005). Breschi and Malerba (1997) sets this study at the sectoral level (Sectoral Innovation System - SIS), while Cooke et al
(1997) and others delimit to the regional level (Regional Innovation System - RIS).

In this study, we use the typology of sectorality starting from a multidimensional view of the dynamics and the integration of various sectors involved directly or indirectly related to the market through a complex network of interactions between its agents. The advantage of sectoral systemic view is at the possibility of greater knowledge of the structure and the boundaries of the sector, of its agents and their interactions, the learning processes, of innovation and production, the dynamics of processing and of factors that determine the performance of firms (Malerba, 2002).

It's worth noting that, when analyzing an industrial sector, its dynamics is linked with the actual technological regime of that industry, this approach is well structured in Malerba's (2002) conception on Sectoral Innovation Systems (SIS).

The author acknowledges the sectoral innovation and production systems as consisting of a set of products and agents directly or indirectly related to the market. These agents may be individuals or organizations at various aggregation levels, with specific learning processes, competencies, organizational structures, beliefs, goals and behaviors, which interact through processes of communication, exchanges, cooperation, competition and commands. Another approach is that this system has a specific base of knowledge, institutionalisms, technologies, inputs and demands which transform from the co-evolution of these elements themselves.

Malerba (2005) describes a SIS through three analytical dimensions, as we can see in Figure I, those dimensions are responsible for generating new technologies and innova-

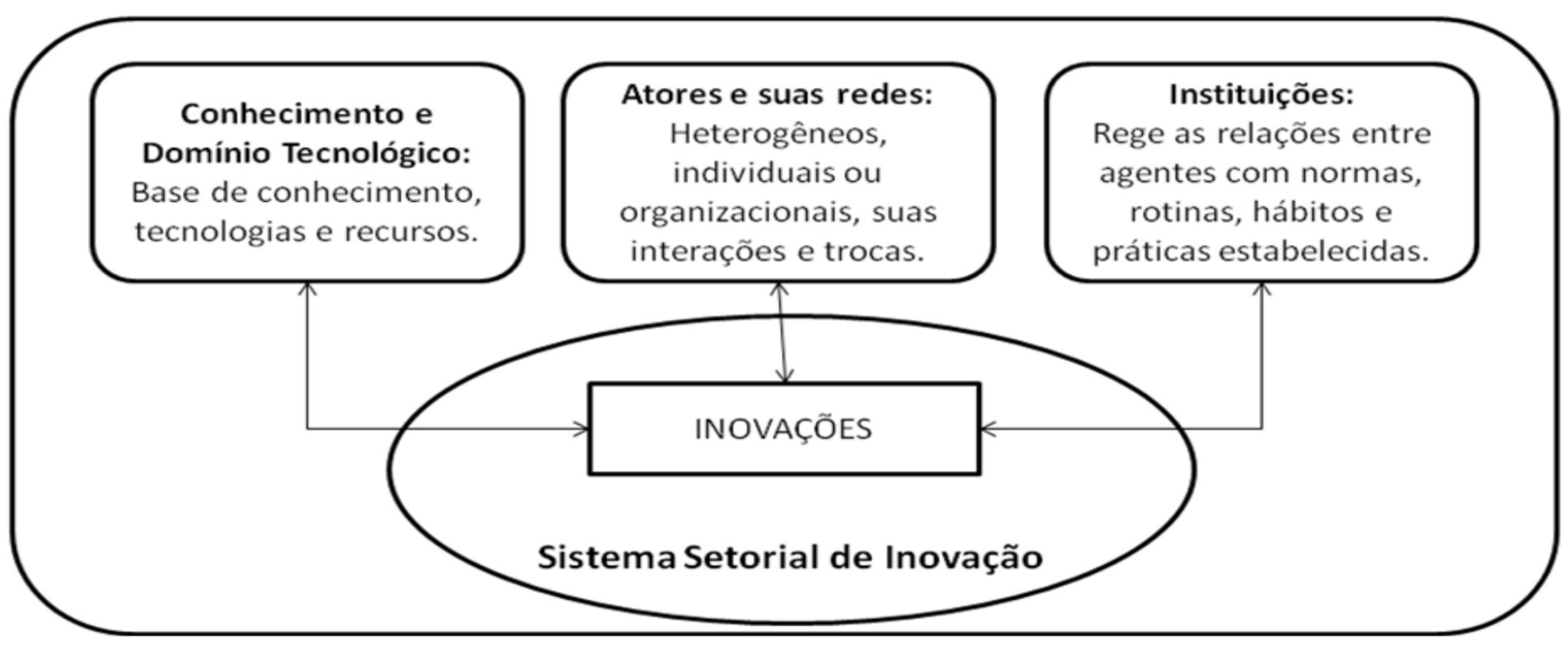

Figure I:The three dimensions of Sectoral Innovation System, according to Malerba $(2002,2005)$. Source:Authors

ISSN: 07I 8-2724. (http://www.jotmi.org)

Journal of Technology Management \& Innovation (c) Universidad Alberto Hurtado, Facultad de Economía y Negocios. 
tion: the knowledge and the technological domain, the actors and their chains, and institutions. These dimensions form the pillars of the SIS concept as a result of interaction between various functional logics, of complexity and dynamism, of benefiting from innovation, which rarely take place in isolation.

In the first dimension, an aspect to be mentioned concerns with the focus on knowledge, in the technological field, in dynamic linkages and complementarities that are the main source of transformation and growth of sectoral systems, generating innovation and change.

In the second dimension, a sector is composed by individuals and / or organizations (agents) at various levels of aggregation, with specific learning processes, competencies, organizational structure, beliefs, goals and behaviors, which interact through communication processes, exchanges, cooperation, competition and commands. Meanwhile, the third, institutions are a compound which include norms, routines, common habits, established practices, rules, laws, and standards that shape the interactions between agents.

Among the studies conducted about the sectorial approach of innovation systems as proposed by Malerba $(2002,2005)$, Rosario (2008) analyzes the national sugarcane agro-industry and mentions that the interaction between research networks in developing innovations is changing the pattern of the sectorial competition. In the analysis of SIS in Alagoas, the organizations can be characterized as the production units of sugar and alcohol, which interact with local and national research centers, enabling tests of new technologies generated by the innovation system and spreading the results.

\section{From Sugar-alcohol to Sugar-energy Industry: Latest Coevolution of Technology and Sectoral Institutions.}

In 200I, Brazil has undergone a reformation in its energy regulation due to a deep crisis; the Brazilian product declined in that year, the crisis was a result of problems in the generation of hydroelectric energy.

This fact has placed the industry, back then sugar-alcohol, in the highlights of national economic scenario, initiating a profound structural transformation of sugarcane agro-industry (Ramos, 2002, Belik \& Vian, 2002, Carvalho, 200 I).

The recent transformation had already started when the Brazilian government released production quotas and dismissed the National Institute of Sugar and Alcohol (IAA), the government body that directly controlled the industrial production sector since the 1930s (Szmrecsányi \& Smith, 1991). Initially, the less efficient firms felt the impact of the extinc- tion of guaranties to purchase sugar and alcohol by PETROBRAS and IAA, respectively. Then, between 1990 and 1996 various demands of these companies were forwarded to the federal government and resulted in the extension of alcohol prices control until 1999, where they were finally fully released (Vian, 2002).

Since 1996, however, the entry of new consumers to the international sugar market has raised the price of this commodity and revitalized the Brazilian sugar industry. The most efficient companies at that time were able to settle a base for significant growth, managing to quickly meet the growing international demand and prepare, unintentionally, to further market changes to come.

The side effects on the Northeast region as a result of the abolishment of PROÁLCOOL and the increased demand for sugar, was the loss of space in domestic production, especially from the 90 s, when the mills in the South- Center began devoting themselves to the production of sugar. In order to follow the expansion of South-Central regions, part of the Northeastern groups have migrated their production between the late ' 90 s and early 2000s, to Minas Gerais and São Paulo and to the Midwest of the country as well.

Thus in 2006, the main sugar and ethanol groups of Alagoas and Pernambuco, the largest producers of sugarcane in the Northeast region, have already produced outside of their homelands an amount equivalent to the entire production of raw material processed in the two states together - about 40 million tons (PROCANA, 20I I). Business groups as Coruripe, Carlos Lyra,Toledo, NDE, Farias, among others, began a process of migration to the South-Central in the country looking to expand their production in lands with higher productivity.

But yet in 1999, with the full liberation of alcohol prices, the sugarcane industry was actually open to a market regime. This fact has triggered two major processes of transformation in the industry structure; on the one hand with the lack of an institutional framework imposed by the government, caused the market agents themselves to search for forming institutions and organizations, seeking to replace the middleman - the government - and find ways to the establish a pricing mechanism (Belik \& Vian, 2002, lel, 2005). This period was transient and turbulent due to various speculations and accusations of cartel price fixing, particularly in alcohol.

However, in 200 I, as noted, the industry once again became important. The energy crisis experienced in Brazil this year revealed a potential for productive diversification for an existing product in season times. The electricity produced from burning the bagasse (the marc) was added to the Brazilian energy matrix, causing several institutional and technological

ISSN: 07 I8-2724. (http://www.jotmi.org) 
developments which affected the sector agents irreversibly. Back then, it was established under the international Kyoto Protocol, which established conditions for the emergence of a low carbon renewable based economy. In this context, Brazilian ethanol from sugar cane becomes a candidate of the first order, since the entire productive, distributive and regulatory structure was being applied since the late 1970s.

In 2003, Brazil began to adopt the flex fuel technology as seen in Chart I - for car engines thereby increasing the internal market demand for ethanol, as occurred in 1974 when the government established the National Alcohol Program (PROÁLCOOL), creating the fuel alcohol market in Brazil.

Thus, the sugar-alcohol agroindustry ceases again to be an industry focused on food, where ethanol production is a response to the fluctuations of international sugar price and sugar becomes an energy industry, while the production focus is on ethanol and electricity.

This can be granted with the recent entry of multinationals in this the industrial sector and the sector consolidation that has taken place. In both cases the priority is the production of ethanol and cogeneration of electricity.

In addition to these market factors, the government has also established an Incentive Program for Alternative Sources of Energy - PROINFA, of the Federal Government, with World Bank funds, the program has set a goal for December 2006, an output of 3300 megawatts (MW) electricity from alternative sources.

These recent institutional frameworks are producing some significant changes in the structure of the sugarcane agroindustry, as well as deepening the differences between the two producing areas in Brazil.

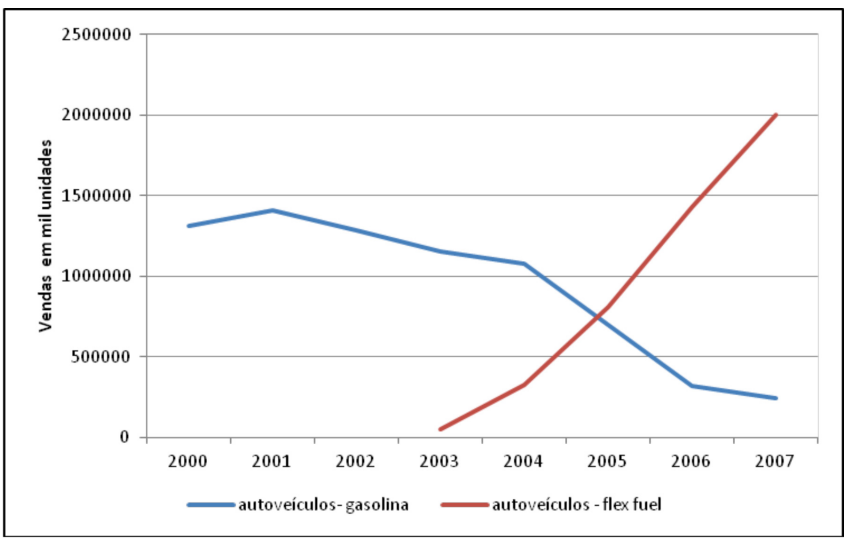

Chart I: Sales of alcohol and gasoline vehicles in units (19802005). Source: Authors with data from IPEADATA, $201 \mathrm{I}$.

\section{Technical progress and innovations in the sugarcane industry.}

The institutional context described so far could not been occurred without a major technological breakthrough of this industry. Since its beginning the sugarcane agro-industry, today, sugar-energy, has gone through several evolutions since the sugar mills were implemented to the modern plants of PROÁLCOOL (Carvalho, 200I, Andrade, 200I).

With PROÁLCOOL emerges the importance of improving the varieties cultivated of sugarcane since the genetics of this species was not directed toward productivity gains and production efficiency needed to support the alcohol program until the mid-1970s. It is important to emphasize here that the plant breeding created some relevant industrial transformations and imposed an innovative dynamics in the sector.

In 1982, a new pricing method was adapted, initially in Alagoas and later in São Paulo. Sugarcane prices were set according to sucrose level (PCTS). This fact has enhanced the research on genetic improvement of cultivars in cane sugar, increasing the average Brazilian sugar production per hectare - see Chart 2. Therefore, if technological progress was previously restricted to the industrial sector, since the implementation of the PCTS innovations advanced to the agricultural part of the production process.

Yet, the sectorial structure toward genetic breeding began in 1968, when military governments began the process of export policies consolidation in Brazil.The Federal Government set up three large public investment programs:

\section{- National Program for Improvement of Sugarcane (Planalsucar). \\ - Rationalization Program of the Sugar Industry. \\ - $\quad$ Support Program Sugar-Alcohol Industry.}

The first two programs began in 1971; the last replaced the second in 1973. Planalsucar was responsible for the development of varieties of sugarcane adapted to the weather and soil conditions in Brazil, since until then these varieties were imported. The Planalsucar is currently being continued by the Interuniversity Network for the Development of Sugar and Alcohol Sector (RIDESA).

After the extinction of the IAA in 1990, the genetic program Planalsucar as well as the physical structure and the technicians responsible for the organ moved to the federal universities located in these states. The research of sugarcane continued and RIDESA was instituted, that is one of the research organizations that is part of the sectoral innovation system. Further discussion of this organization will resume.

ISSN: 07 I 8-2724. (http://www.jotmi.org)

Journal of Technology Management \& Innovation (c) Universidad Alberto Hurtado, Facultad de Economía y Negocios. 
In general, the research organizations directed their efforts to increase the cultivars agricultural efficiency and the industrial production of sugar-alcohol. Currently, research funding comes largely from the plants, with CTC (Sugarcane Technology Center) and RIDESA, from federal governments and states where sugar cane is an important activity, especially in São Paulo, with FAPESP in Alagoas with FAPEAL. PETROBRAS and other multinationals as Monsanto, Du Pont and BASF are also investing in technologies related to this agricultural industry.

As a reference to the research, Monsanto, through the acquired firms CanaVialis and Allelix develops new varieties through genetic sugarcane. CanaVialis is a biotechnology firm which develops sugarcane varieties through classic genetic crossbreeding while Allelyx, deals with advanced genetics and genomics.

The major institutions and firms linked to research in the sector are: the Canavieira Technology Center (CTC), the Technological Research Institute (IPT), the Agrarian Science Center (CCA / UFSCar), Luiz de Queiroz Agronomy School (ESALQ / USP), the Food Technology Institute (ITAL), the Campinas Agronomic Institute (IAC), the São Paulo University (USP), the Campinas University (Unicamp), the Federal University of São Carlos (UFSCar), UNESP, SABESP, the Biological Institute, the Ethanol Industry interuniversity Network of Development - RIDESA, the Science and Technology of Bioethanol Center (CTBE), the Paulista Center for Bioenergy Research and the EMBRAPA Agro-energy.
The Canavieira Technology Center - CTC, is an organization that follows the Technology Center COPERSUCAR, a traditional research center maintained by the Cooperative of Sugarcane, Sugar and Ethanol producers in the State of São Paulo - COPERSUCAR Ltda. The Technology Center COPERSUCAR was created in 1970 and was responsible for numerous technological developments in the sector including the creation of varieties of sugar cane SP, which today hold for approximately $40 \%$ of Brazilian sugarcane. The CTC also perform research, combating plagues through biological control, including using sugar as an input of organic pesticides. This center is a private company in which members represent about $1 / 3$ of the sugar and ethanol producers in Brazil, its action went beyond the state of São Paulo and is currently expanding to the Northeast, with the creation of new partnerships and an experimental center in Alagoas.

In São Paulo, IAC develops the breeding program PROCANA. The program integrates its activities in various areas of sugarcane research. The main project is the breeding which aimed at obtaining more productive varieties of sugarcane, with greater richness in sugar and other features that provide economic advantages. Moreover, Sao Paulo has the Paulista Agribusiness Technology Agency (APTA), composed of six research institutes and coordinates research on sugar and ethanol.The interaction between organizations is complex both in research partnership and in technology transfer, the main beneficiaries are sugarcane suppliers cooperatives, universities and EMBRAPA, scattered across several activities lines, regions and goals (Fonseca, Silveira, Rosário, Mernard, \& Ely, 2007).

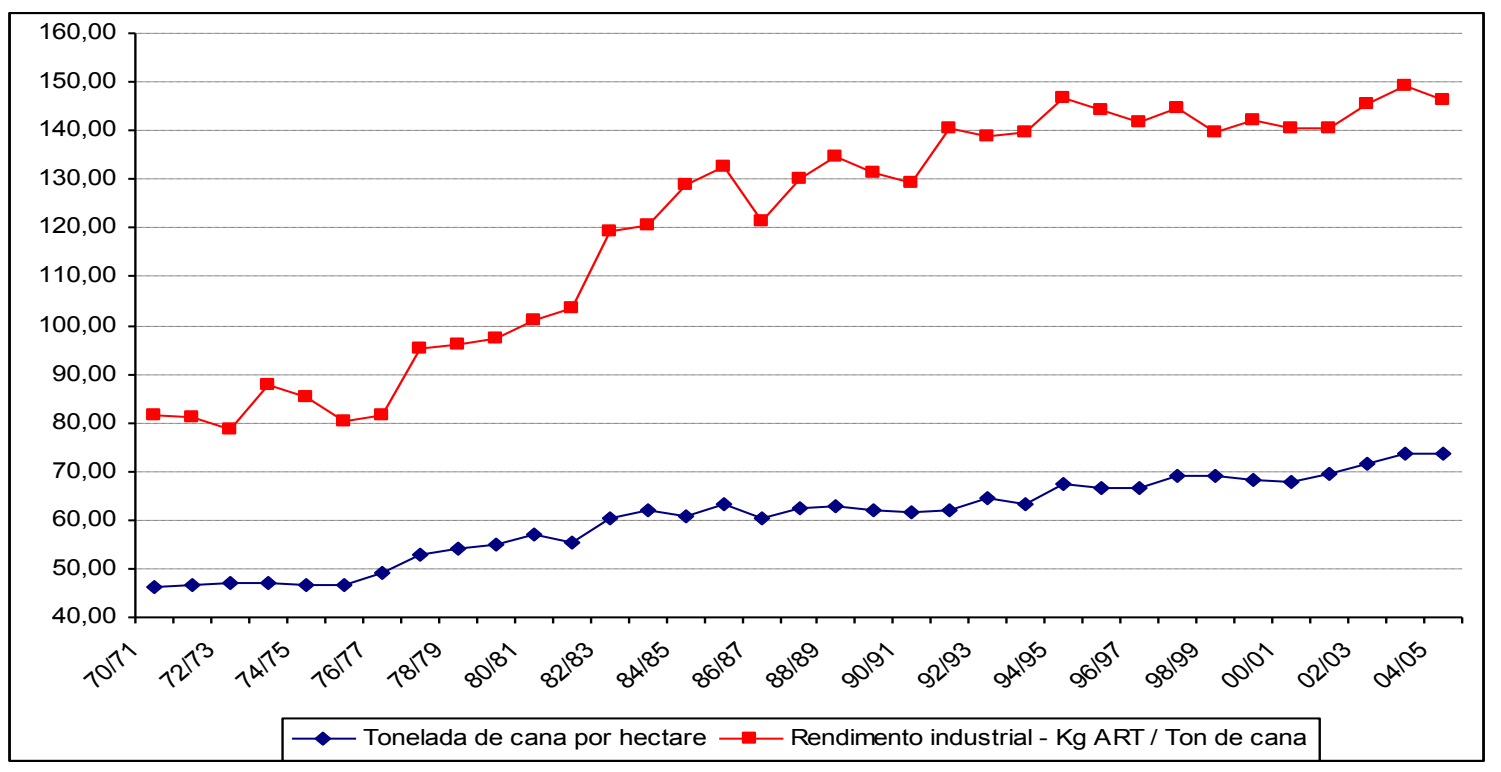

Chart 2: Indicators of Industrial and Agricultural Productivity in TRS*. Source: INFOSUCRO - Statistical Information quoted from (Fonseca, Silveira, Rosário, Mernard \& Ely, 2007).

Note: $*$ TRS $=$ total reducing sugar per ton of sugarcane.

ISSN: 07I 8-2724. (http://www.jotmi.org)

Journal of Technology Management \& Innovation (c) Universidad Alberto Hurtado, Facultad de Economía y Negocios. 
The Center for Science and Technology of Bioethanol in Campinas, São Paulo, is a national laboratory belongs to the Ministry of Science and Technology (MCT) and integrates the National Center of Energy and Materials Research (CNPEM). Although the structure of this organization is still being formed, there already partnerships with EMBRAPA and foreign organizations for research on sugarcane.

By late 2009, a partnership between the Sao Paulo government, the state's public universities and FAPESP was articulated for the creation of the Paulista Center for Bioenergy Research, which aims to strengthen the research effort and training of high-level skilled manpower in the state of São Paulo.

With the importance of sugarcane as an energy source, several other research entities jointed partnerships for the development of knowledge applied to sugarcane. One example that may be cited is EMBRAPA and the Bahian Agricultural Development Company (EBDA).

In the case of EMBRAPA, a specialized unit was created in order to deal with Agro-energy sources derived of agricultural products. This unit will join partnerships with other research organizations which have a portfolio of advanced research projects in-order to find more advanced technological solutions for the industry.

The second case, of EBDA in partnership with the Campinas Agronomic Institute (IAC) and the Bahia Foundation, is of exploring technological opportunity as the development of sugarcane cultivars adapted to the savanna of Bahia, new frontier in the production of sugarcane.
Multinational from the agribusiness, such as, Du Pont and Britsh Petroleum (BP), also invest in sugarcane research, by forming partnerships and joint ventures with operating plants or forming new firms to produce a butanol called Butamax.Apart of these companies, Basf is reviving its partnerships with some mills in-order to develop modified varieties and pesticides. Yet, other multinational firms are conducting researches in the industry, as Syngenta - with fertilizers and bio-activators; Novozymes - 2nd generation ethanol, development of polypropylene sugarcane (along with Braskem) and Amyris, in the production of sugarcane diesel.

PETROBRAS is researching and developing a production processes for 2nd generation ethanol and kerosene for aviation, the firm also form joint ventures with installed ethanol production plants. The DEDINI has been investing since the 1980s in the extraction of ethanol from sugarcane bagasse, the firm currently has a partnership with FAPESP and CTC regarding research in this area.

\section{Sectorial knowledge aggregation.}

In a survey conducted for the research created in this article, from the National Institute of Industrial Property (INPI) database, a great instability in R\&D effort is encountered in the agroindustry. In Figure 3 we can check the total volume of patents (sugar and ethanol), both regarding to products and process inventions. The highest peak in patenting coincides exactly with the period of the beginning of PROALCOOL, between 1975 and 1982. However, since 1983, the effort cooled down when the state could no longer boost R\&D with direct investments as a result of the Brazilian fiscal crisis between 1982 and 2000.

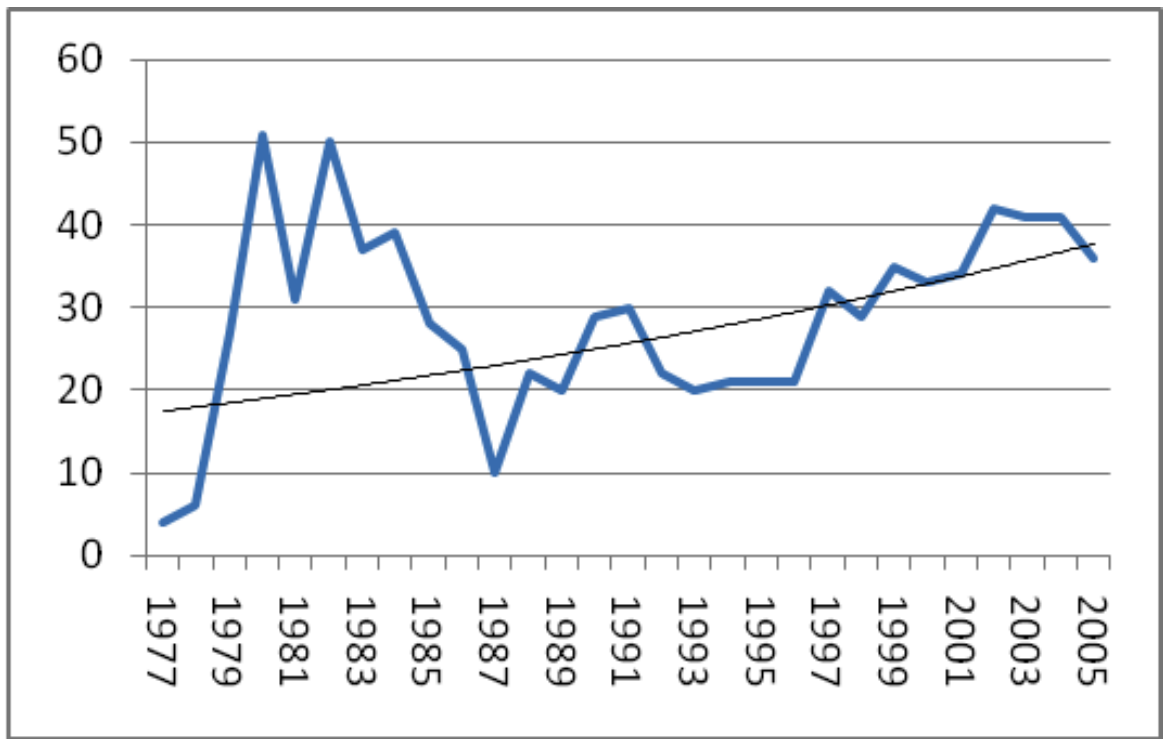

Chart 3 - Products and processes patents related to sugar and alcohol, registered in INPI, between 1977 and 2005 (the patent/year). Source:Authors, based on data from the PTO.

ISSN: 07 I8-2724. (http://www.jotmi.org)

Journal of Technology Management \& Innovation (c) Universidad Alberto Hurtado, Facultad de Economía y Negocios. 
Another important subject is the aggregation of R\&D, verified by the trend line in Chart 3. The innovation effort continues growing, even after the "valley" observed in 1987, showing that past innovations were reflected in a significant way in the future development of new patents, even if those has not been significant. This may be reflected from the reduction in R\&D investments made in the sugarcane agroindustry. During the rise of Proálcool $2 \%$ of the gross sales in the industry were invested in research and development. Currently, this percentage is no more than $0.25 \%$, even after a real increase in sales of this agroindustry (Albuquerquer; Silva, 2008).

Due to the incentives given to alcohol researches, in Figure 4 , we can observe the growth in patents numbers related to fuel production, but with the increasing importance of the sugar agro-industry revenue, from the mid-1990, there is increased registration of patents related to the commodity production.

But it is important to note two things in Charts 3 and 4. The first concerns the effort in R\&D which, although growing slowly, continued rising during the 90's, largely due to private effort. It is also possible to notice that there was an average reduction of $4 \%$ in the number of patents related to alcohol between 1990 and 2005, that may result from the agroindustry lack of interest in that product, at least until 2004.

Since 2004, the agroindustry is experiencing a period in which it resumes to alcohol production. In the 2007/2006 season compared to $2003 / 2002$, for instant, ethanol production grew by $20 \%$ compared to sugar production. However, these values are recent and the growth in ethanol production is not consolidated enough to create an impact on the current R\&D efforts being made in the industry.
Finally, it is worth noting that this industry has a vast network of public and private interactions and relationships of R\&D linked to sugarcane and its sub-products which cumulatively step forward and ensuring the international competitiveness and sustained growth of the industry in the last 40 years.

\section{Methodological Approach}

The research originated in this article was implemented in two phases. Initially, documented data was collected from institutes and organizations focused on research in this segment. Then, primary data was collected to obtain an answer to the question asked in the introduction. Later, the study was descriptively sealed, based on the survey method.

The primary data collection was realized by a survey done with a target population of 24 sugarcane industries in the state of Alagoas, set from the registry made by the Industry Federation of the State of Alagoas (FIEA, 2007). Although all companies have been contacted, only 16 responded to the questionnaire. An application of a questionnaire to other members of the sectoral system of innovation, in order to intent understanding the interactions from the perspective of the production units was not an object of the analysis. For confidentiality, the surveyed units are not identified.

The survey instrument was divided into three blocks. The first block aimed to measure the innovations developed by companies in 2008, considering three aspects: new products launched, new processes developed and patents and registered. The second searched to identify the evolution of the interaction network, identifying the level of relationship between the industry firms and other organizations (competitors, suppliers, research centers, consulting firms, among others). In the third block the objective was to validate the

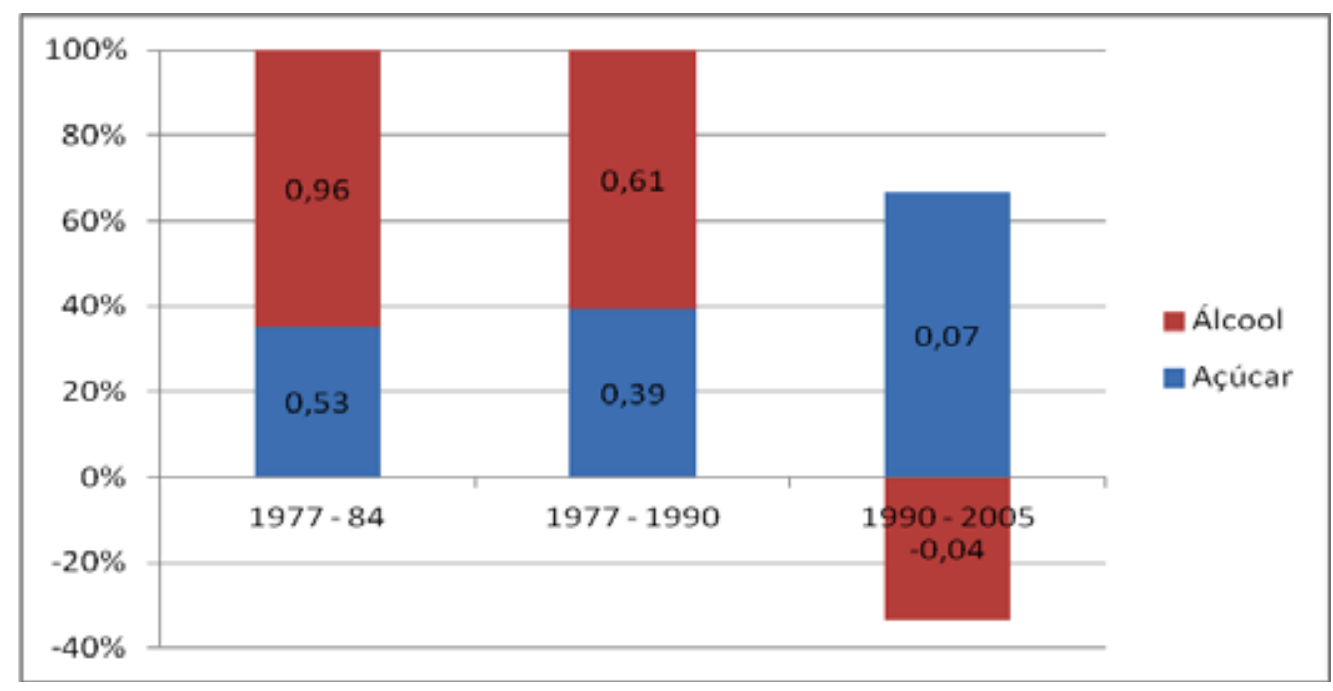

Chart 4:Average Annual Growth Rate in Number of Patents Source: Prepared by the author with data from INPI

ISSN: 07I 8-2724. (http://www.jotmi.org)

Journal of Technology Management \& Innovation (c) Universidad Alberto Hurtado, Facultad de Economía y Negocios. 
degree of association between the SSI dimensions from the perception of the production units in relation to the proxy variables of those dimensions.

The primary data was analyzed through the use of descriptive statistical tests in-order to establish the profile and the characteristics of the firms innovation. In order to test the correlation and association between the data, we used two non-parametric techniques: a) Kendall concordance coefficient $\tau$.b) Spearman $\rho$ test. The significance levels established in the study were: $p=0.05$ and $p=0.01$.

\section{Data Analysis and Results}

\section{Enterprises profile and innovations developed.}

The state of Alagoas has produced, with its 24 production units in 2008/09, 29.8 million tons of sugarcane, 2.6 million tons of sugar and 852,600 cubic meters of alcohol, according to the State of Alagoas Sugar and Alcohol Industry Syndicate. In the industrial structure of the sugarcane agroindustry in Alagoas, the mills operate with a minimum efficient scale (EME) of I,206 million tons of cane crushed / year and, according to Figure 5, about half of the firms in Alagoas are in that zone, the other half can be considered inefficient since they operate with increasing costs. This information enables us to understand that inefficiencies can be derived, as well, from obsolete production technologies, since the average cost of smaller units are higher than of other production units.

However, when asked about innovations, firms, in general, reported to have not generated any new product or have registered patents in 2008. Nevertheless, all realized innovation in processes conducted for the improvement of productivity and efficiency in production scale. Particularly it is possible to see the adoption of new cultivars as an innovation in the agricultural process.

A relevant data in the research is the fact that all firms report an investment of a significant amount of their revenues on Research and Development (R\&D), but in average this value is no more than $0.1 \%$ of the total industry revenue in Alagoas. It is feasible, since the twelve partners of Plants Breeding Program of Sugarcane (PMGCA) of RIDESA in Alagoas, invest about 2 million Reals in research for new cultivars . In general, $80 \%$ of firms presented the highest investments in R\&D in agriculture genetic research. The majority of the firms (85\%) have laboratories for the analysis of sugar, alcohol and of the sugarcane itself. Apart of the research, production units in Alagoas own the most modern drip irrigation system in the country, reaching the same level of productivity of the South-Center (Franco, 20I I), thus representing another example for the adoption of advanced technique.

According to the Center of Technological Innovation - NIT at the Federal University of Alagoas, between the years 2000 to 2008 , only two new types of cultivars were recorded in the Ministry of Agriculture. In 2010, RIDESA released 13 new varieties of sugarcane in Brazil, five of those were fully developed in Alagoas (AGROLINK, 20I0). Yet, considering data from NIT/ UFAL, the manufacturing firms and RIDESA, in the state of Alagoas, currently counts with twelve collaborative researches contracts.

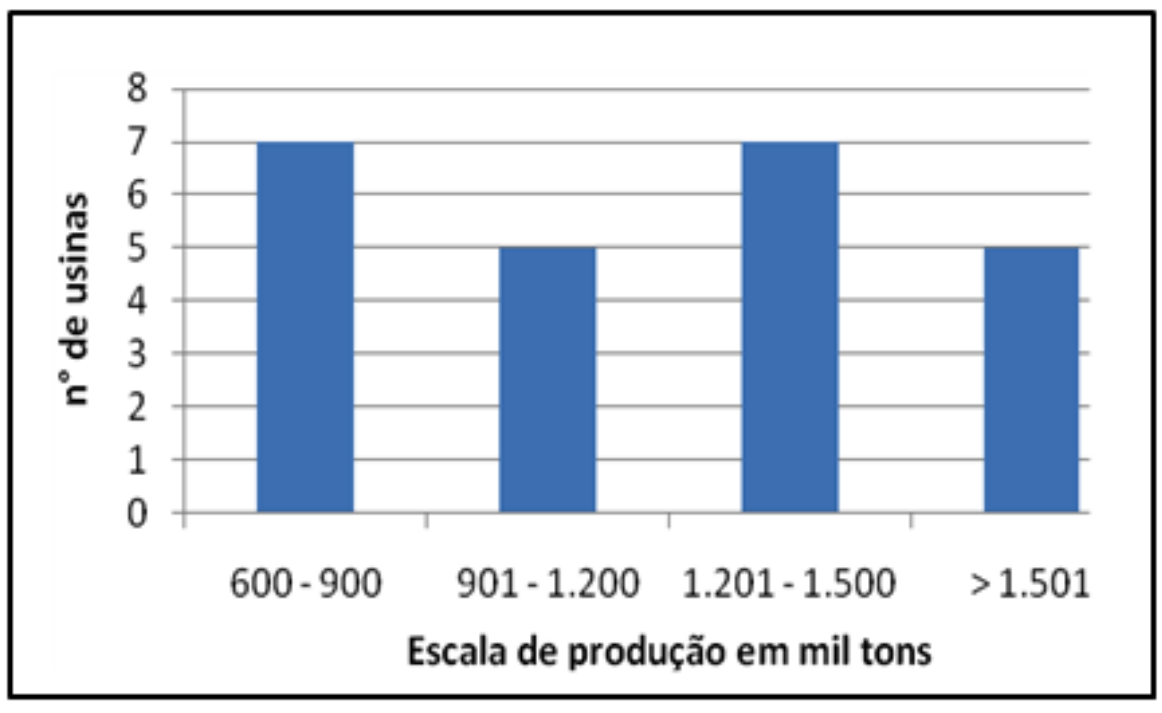

Chart 5: Distribution of production scales in thousand tones/year in the 2007/08 season. Source: Research data / Sindaçúcar - AL

ISSN: 07 I8-2724. (http://www.jotmi.org) 
The research network of the northeastern sectorial system.

Among the sectoral innovation system members, we can cite some public and private organizations, which hold for a stake in the sector's development at many different levels, such as: Inter-University Network for the Development of the Sugar-Alcohol Industry (RIDESA), the Regional Cooperative of Sugar and Alcohol Producers in Alagoas, the Sugarcane Planters Association of Alagoas, the State of Alagoas Sugar and Alcohol Industry Syndicate, development funding and support agencies, as can be seen in Table I.
The RIDESA constitutes a sugarcane research structure for the development of new varieties of sugarcane and the ideal management method to increase the production. This network was initially established through an agreement between seven federal universities (UFPR, UFSCar, UFV, UFRR), UFSE, and UFAL UFRPE) who were located in the operation areas of the Coordination's of former Planalsucar, of which the technical staff and infrastructure of the coordinating and experimental stations headquarters were absorbed. With the support of a significant part of this sector, through agreements and contracts for technology transfer, the RIDESA began to perform its duties in 1991.

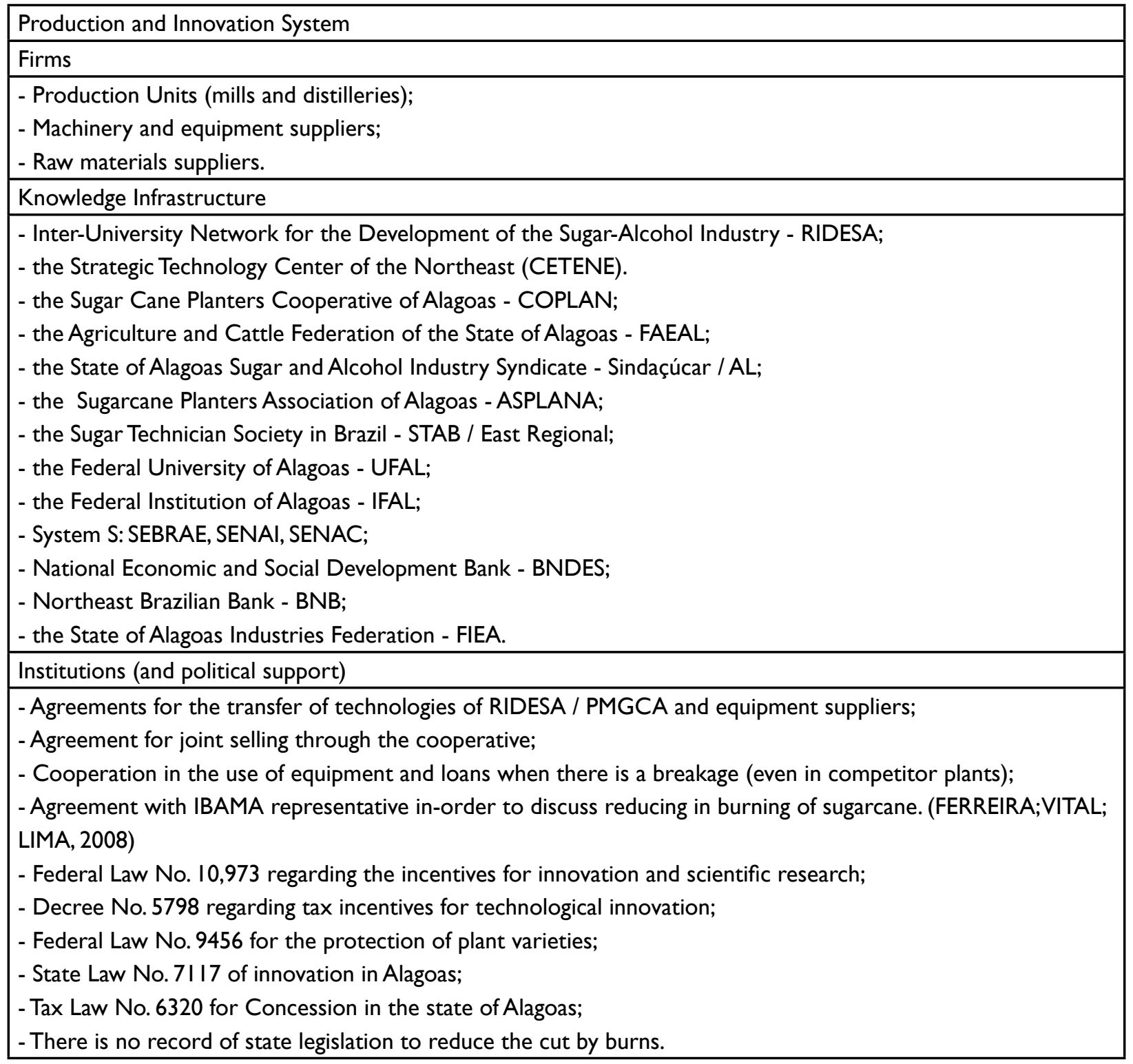

Table I Sectoral Innovation System Units. Source:Authors

ISSN: 07 I8-2724. (http://www.jotmi.org)

Journal of Technology Management \& Innovation (c) Universidad Alberto Hurtado, Facultad de Economía y Negocios. 
The network's Universities provide technical and institutional support to the experimental stations which are strategically located in states where the culture of sugarcane is represents higher expression. The emphasis of researches in the experimental stations refers to the maintenance and continuity of the research related to Breeding Program of Sugarcane (PMGCA). Currently, the abbreviation RB cultivars, previously developed by the defunct Planalsucar, are presented in over $54 \%$ of sugarcane cultivated area in the country and, in some regions, may represent up to $70 \%$ of the commercial planting.

RIDESA constitutes a research and teaching framework for sugarcane, with 142 researchers and 83 technicians from eight federal universities, 15 experimental stations and 52 laboratories for the development of new varieties of sugarcane and the ideal management method to increase the production (Barbosa, 2007). In Alagoas and Pernambuco, the network also counts with the research support given by 40 mills. The main asset of the PMGCA is the germplasma bank located in the Flowering Station and the Serra do Ouro (UFAL), in the municipality of Murici, State of Alagoas. There are over 2000 genotypes reunited among them: cultivars, clones, other species, related to the genus Saccharin and imported cultivars from different regions of the world (Ridesa, 2009).

The local universities, linked to the network (and UFAL; UFRPE), are responsible for about $30 \%$ of the RB varieties released.After the network creation, $37 \mathrm{RB}$ cultivars have already been released to farmers (Albuquerque \& Silva, 2008).

Table 2 allows us to realize the importance of researches conducted by RIDESA, especially in the state of Alagoas, which in the last year released five new varieties of sugarcane, ahead of other research entities of the more competitive regions in the Center-South.

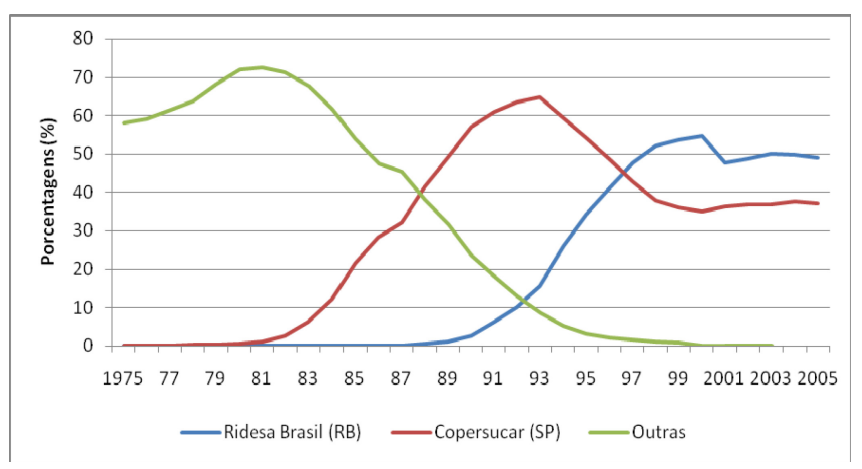

Figure 6:An evolution of a percentage of the total planted area with sugarcane varieties in Brazil.

Source: Survey data from the PMGCA / RIDESA

(BARBOSA, 2007).
Chart 7 complements the previous idea, showing the percentage of sugarcane varieties in Brazil registered by leading research institutions. As noted, the highest percentage record comes from universities associated with RIDESA (30.9\%) (labeled in blue). Followed by Coopersucar.

It is noteworthy that in the data presented in the chart above, only 3 of varieties of RIDESA-UFAL and RIDESA-UFV have a provisional protection, the others are permanent. That helps to realize the importance of researches conducted by RIDESA, as well as its partner in Alagoas regarding the sectorial scientific development. In 2010 alone, as seen in Table 2 , UFAL released five new varieties out of the 13 varieties released by RIDESA network throughout Brazil.

\begin{tabular}{|l|l|l|}
\hline State & $\begin{array}{l}\text { Federal University } \\
\text { Partner }\end{array}$ & varieties RB \\
\hline Alagoas & UFAL & RB 931003 \\
& & RB 9310II \\
RB 95I54I & RB 987I0 \\
& & RB 99395 \\
\hline Pernambuco & UFRPE & RB 962962 \\
& & RB 002504 \\
\hline Paraná & UFPR & RB 946903 \\
& & RB 9569II \\
\hline São Paulo e & UFSCar & RB 966928 \\
Mato Grosso & & RB 965917 \\
do Sul & & \\
\hline
\end{tabular}

Table 2 RB Varieties launched in 2010. Source: RIDESA (2010)

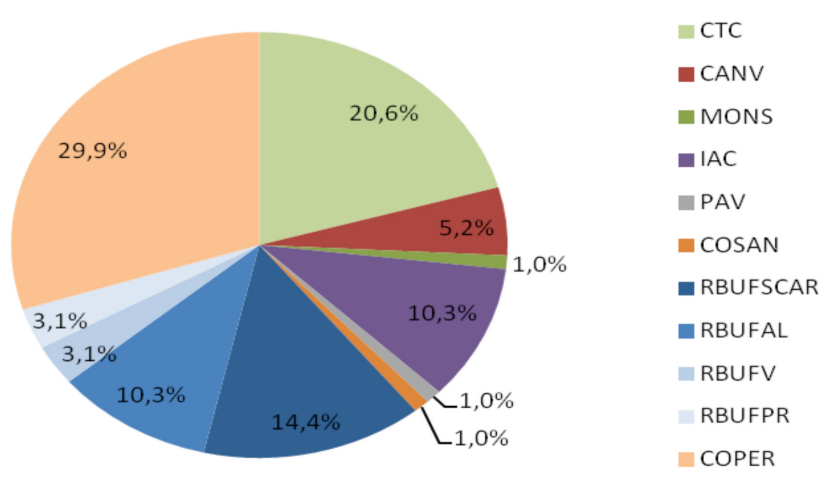

Chart 7: Percentages of Protected Sugarcane Varieties Source:Authors with data from MAP (20II)

ISSN: 07 I8-2724. (http://www.jotmi.org) 
Figure 8 presents the distribution of the varieties usage in Alagoas, where most of the planted area has varieties of RIDESA, who's cultivars are more adapted and were directly developed with mills in Alagoas, Pernambuco, Bahia and Maranhão.

If from one hand, the fact that the private sector invests in research in Brazil gains some relevance, on the other hand, as a research is cooperative, the degree of accessibility to new technologies is high and does not guarantee the appropriability of for a particular firm to benefit from innovation, that is, one of the reasons for the low concentration of this agroindustry is in the fact that the technology is widely accessible.

Another regional R\&D organ is the Strategic Technology Center of the (CETENE). This center aims to conduct studies, interdisciplinary projects, research activity, development and innovation, in strategic areas for the development of the Brazilian Northeast. This center is an initiative of the Ministry of Science and Technology which focuses on bioindustry meristems (clones) of high productive sugarcane,

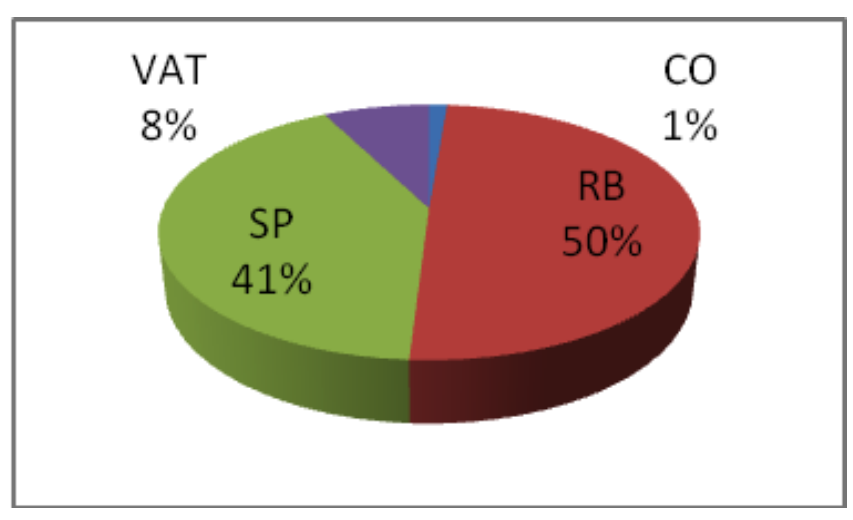

Chart 8: Varieties Performance in Alagoas

(\% of harvested tons of sugarcane)

Source:Authors with data from PMGCA / UFAL / Sindaçúcar - AL with the aim of distributing the clones to small producers in the forested area of the northeast.

Fonseca and Rosario (2007) report that this effort is of extremely important for the productivity development of that agroindustry, but on the other hand, the diffusion of new technologies for the pool of firms who participate in financing R\&D (RIDESA and the Canavieira Technology Center - CTC), does not guarantee the individual appropriability to benefit from innovating new varieties of sugarcane or even from a new production technique, whether agricultural or industrial.

This guarantee will depend on the set of complementary assets established between technology developers and its users. In the case of cultivars, the main complementary asset is the technology transfer contracts and the payments of royalties between CTC and RIDESA to the plants or sugarcane suppliers. However, the surveillance of varieties usage is too difficult and expensive for these research centers to establish.

More recently, RIDESA has institutionally strengthened with the approximation between the membered universities concerning the standardization, in a national scope, of technology transfer contracts, royalty payments and research organization.

\section{Evaluation of network interactions evolution.}

In order to answer the research question concerning the interactions between the agents, this session presents the degree of interactions between "sugar-energy firms (production mills) and organizations (other firms or government organs)," "Sugar-energy firms and Competitors" and "Sugarenergy firms and Suppliers". These interactions strengthen the network of agents and ensure collective learning, knowledge diffusion and the use of innovations in the innovation systems.

\begin{tabular}{|l|l|l|}
\hline Organization & Average & Standard Deviation \\
\hline Suppliers & 3,75 & 0,452 \\
\hline Financial Institutions & 3,58 & 0,900 \\
\hline Customers & 3,58 & 0,900 \\
\hline Universities & 3,33 & 0,651 \\
\hline Concorrentes & 3,33 & 0,492 \\
\hline Public Agencies & 3,17 & 0,835 \\
\hline Associations & 3,08 & 0,289 \\
\hline Unions & 3,00 & 0,000 \\
\hline
\end{tabular}

Table I Interaction of Sugar-energy firms x Sugar-energy Organizations x Sugar-energy Sectorial Innovations System. Source: research data

ISSN: 07I 8-2724. (http://www.jotmi.org)

Journal of Technology Management \& Innovation (c) Universidad Alberto Hurtado, Facultad de Economía y Negocios. 
In this paper we used a five points Likert-type scale, ranging from I (strongly reduced) to 5 (strongly increased). The marking of the two lowest values signals a decrease in the interaction between the agents in recent years and an the highest values indicates the improvement of interaction. The intermediate value (3) indicates that the relationship was "stable", that is, there was no change in the degree of relationship between the respondent and other agent of the SIS. In order to understand the relationships between sugarenergy firms and other organizations in the system, the average and the standard deviations were extracted from the responses. In this research, the favorable results are averages above the level of 3 . In general, in the respondents conception, the evolution of relations coincides with the degree of interaction already exists, or in other words, those who positively developed were the relations between agents who already had interaction, as shown in Table I.

Generally, Table I identifies that the evolution of interactions was positive, but with no change, since the average was around the "rank" 3. That shows that the industry structure in Alagoas is relatively stable, as the relationships between agents determine the industrial dynamics (Malerba, 2005).

However, when analyzing in terms of Financial Institutions, customers and public agencies, the deviation is large, indicating that not all firms hold the same perception. In the case of financial institutions and customers, the high deviation may reflect by the 2008 crisis, since domestic and international credit was practically extinct, causing changes in the relationships between plants, banks and the supply to customers. The deviation with respect to public agencies may reflect the increased supervision regarding labor and environment. The universities also represent a significant deviation, which may reflect the release of new cultivars in the last 5 years, such a situation has not occurred since the late 1990s.

After analyzing the interactions between the different agents, we will evaluate the relationships types that the units hold

\begin{tabular}{|l|l|l|}
\hline Interaction type & Average & $\begin{array}{l}\text { Standard } \\
\text { Deviation }\end{array}$ \\
\hline $\begin{array}{l}\text { Clean Technologies' } \\
\text { Equipments }\end{array}$ & 3,75 & 0,452 \\
0,492 \\
\hline Commun Technologies & 3,67 & 0,492 \\
\hline $\begin{array}{l}\text { Test for the development of } \\
\text { new products }\end{array}$ & 3,33 & 0,492 \\
\hline empowerment & 3,33 & 0,492 \\
\hline Marketing & 3,25 & 0,452 \\
\hline
\end{tabular}

Table 2 Types of Cooperation among Competitors within the Agroindustry in Alagoas. Source: research data with two typical agents related to the market: competitors and suppliers. Among competitors, the interaction actually treated here is cooperation, i.e., exchange of information, production techniques and even equipment between the firms. The data is displayed in Table 2 and uses the same scale as the previous table.

Analyzing these interactions, in general, we can note that the relations of cooperation between firms are stable, since deviations are practically the same and no proxy variable of the relationship has a value greater than 4 . But it is worth emphasizing the highest average in information exchange regarding clean technologies and production technologies (equipment and common), initially showing that the environmental concern is relevant, as shown in Table I with respect to public agencies, and currently very much in vogue to agricultural production. The production technology is an important factor for the plants since some of them are below the efficient scale, and in northeast Brazil, the soil and climatic factors establish a pattern of a search for improvement in productivity indicators more intensively than in the South-Center.

Table 3 shows the factors where the production units interact with their suppliers. For that purpose we used the mean, as can be seen in Table 3. In this analysis it was possible to observe that the largest interaction with suppliers was related to the section access to equipment and inputs (purchase and technological knowledge). In particular, the interactions take part with machinery and equipment suppliers who transfer new technologies. This factor is typical for the Brazilian industry since market opening in the 1990s (Ferraz, Kupfer \& looty, 2003).

It is worth to emphasize that testing for new product development is highlighted in the interaction process. This is an important point, since despite the fact that the SIS induces

\begin{tabular}{|l|l|l|}
\hline Interaction types & Average & $\begin{array}{l}\text { Standard } \\
\text { Deviation }\end{array}$ \\
\hline Access to equipment and inputs & 3,83 & 0,577 \\
\hline $\begin{array}{l}\text { Test for the development of new } \\
\text { products }\end{array}$ & 3,75 & 0,622 \\
\hline Technical assistance & 3,42 & 0,793 \\
\hline $\begin{array}{l}\text { Acquisition of cleaner technolo- } \\
\text { gies }\end{array}$ & 3,33 & 0,65 I \\
\hline Technology transfer & 3,33 & 0,492 \\
\hline Joint Marketing Share & 3,00 & 0,000 \\
\hline
\end{tabular}

Table 3 Interaction types Plants $x$ Suppliers. Source: research data

ISSN: 07 I8-2724. (http://www.jotmi.org)

Journal of Technology Management \& Innovation (c) Universidad Alberto Hurtado, Facultad de Economía y Negocios. 
innovations primarily in agriculture; the industry searches for improvement and development of new machinery and equipment via exchange of knowledge with equipment manufacturers, such in the case of Dedini.

This is a typical example of a common learning-by-doing process in traditional industries (Pavitt, 1984, p. 350, Bell \& Albu, p. 1728). Moreover, the variable Technical Assistance showed the highest standard deviation, since the relationships between firms and their suppliers are not homogeneous as some suppliers do not offer continuous assistance for machinery, equipment and systems, leaving the firm to depend on external consultants and assistance.

It is relevant, as well, the deviation in the item "purchase of clean technologies". This may exactly represent the size and efficiency gaps between the plants, which has an influence on the answers, showing that there is no homogeneity in the acquisition of these technologies.

\section{Firms perception regarding the relevance of the SIS analysis dimensions.}

In this section we present the analytical dimensions and the degree of association between them in the perception of the interviewed firms, as an indication for how each dimension may be relevant to the structure and dynamics of the industrial sector, in terms of Malerba (2005).

Given this, first, were evaluated, using the average, the participation of the dimensions (organizations, institutions and technologies), in an integrated manner, in the sectoral innovation system. For this analysis we considered, as well, a fivepoint Likert-type scale, where I represents the dimension which has the lowest relevance to the sector reality, while 5 means the highest level of importance in the sector dynamics. Respondents were based on personal perceptions. That information can be observed in Table 4 .

The table below indicates that the dimension "Organizations" presents the highest degree of relevance to the sector in Alagoas, allowing to assess that for the surveyed firms, the interaction with other organizations (competitors, suppliers, and support organizations) is the key element for the firm's

\begin{tabular}{|l|l|l|}
\hline Analytical dimensions of SIS & Average & $\begin{array}{l}\text { Standard } \\
\text { Deviation }\end{array}$ \\
\hline Organizations & 4,19 & 0,443 \\
\hline Technologies & 3,69 & 0,661 \\
\hline Institutions & 3,03 & 0,937 \\
\hline
\end{tabular}

Table 4 Perception regarding the Relevance Degree of Analytical Dimensions. Source: research data development activities, dissemination and use of knowledge and innovation, since that was the dimension with the highest average and the lowest standard deviation, 4.19 and 0.0443 , respectively. This fact reinforces the discussion from the previous sections - see tables I and 3, indicating that the major advances in knowledge and in the technologies used in the industry arrives from machinery and equipment suppliers and from public R\&D, particularly from RIDESA.

The dimension "Technologies" comes second in terms of relevance within this sectoral innovation system. This fact is related to the generation and dissemination of technological knowledge. However, as stated above, the plants are, to a large extent, supplier dominated - dominated by technological development of its suppliers, according to Pavitt (1984).

Thus, innovation is "entering" the plants via the purchase of equipment, or even by partnerships with suppliers with the aim of technologies development. In these partnerships the focus is on the development and diffusion of new sugarcane varieties along with RIDESA or CTC. In such cases, the mills cede part of their land for testing and development of cultivars. In other partnerships, the equipment manufacturers perform tests during the harvest season in different processes for the production of sugar and ethanol. The high standard deviation may reflect the heterogeneity of technologies and production efficiencies noticed in the mills in Alagoas.

Finally, "Institutions" were cited as the dimension with the lowest degree of relevance. This fact can be explained by the sector's deregulation, being coordinated by the market. Yet, by recent laws and agreements as the Plant Variety Protection Act, as already mentioned, it is observed that environmental laws are the sector's most remarkable.

However, the rank 3 can represent apart from less relevant, a relative indifference or unawareness of agents in relation to this aspect. Indifference is plausible for the productive stability observed in Alagoas, since it was the only productive state in the Northeast that has not drastically reduced its production between 1994 and 2008, in contrast, it increased its productivity and assured some international markets such as Russia, some American quotas and preferences and the Middle East.

Moreover, the high standard deviation may indicate that the most efficient firms are observing changes in environmental law and labor as well as moving forward technologically and improving production efficiency. This is important to Alagoas, since the state has six economic groups relevant to the national scenario, of which 3 were among the 20 largest in Brazil in the 2007-08 season (UDOP, 2009). But the standard deviation may be showing, as well, divergences in the plants

ISSN: 07 I8-2724. (http://www.jotmi.org)

Journal of Technology Management \& Innovation (c) Universidad Alberto Hurtado, Facultad de Economía y Negocios. 
position regarding regulations. This feature can be understood when one observes that only few production units are adept to quality certifications, for example.

The underlying issue here is that the abstract element of coevolution of technologies and institutions is not noticed by the firms. The co-evolution identifies innovation as a social construction, as such, it needs the joint evolution of institutions and industry structure to occur. That is, given that the institutions are the element who shapes the relations in the economic environment, its evolution also involves the evolution of competitive environment (industrial structure) and the competitive "arms" of the agents (innovations). The innovations are feeding back the cycle, requiring new institutional settings, which, in turn, trigger new organizational forms and new industrial organization, and so on.

As the organizational structures of Northwestern firms in the sector does not experience changes which are common in the South-Center regions, and in addition, the regulation of labor and environment in Alagoas is not imposing the plants with an additional production and transaction costs. Then, a low average in the perception scale induces the interpretation that the dimension "institutions" is not seen as defining new strategies and innovations for firms, at least regarding the recent institutional changes.
It is important to highlight the stagnation of this industry in the Northeast. In fact, the dynamic axis of sugarcane production is currently in the South-Center regions.

Finally, the dimensions posed by Malerba (2002), allow us to understand which processes impel the industrial dynamics, the production migration from the Northeast to the SouthCenter, the consolidation of large groups on the expense of independent units, the entry of new products with the advantages in sugar's relative prices and the new organizational and institutional settings which are changing the industry structure and the evolution of knowledge, technology, agents and sectoral institutions.

\section{The measure and confirmation of the association between the Analytical dimensions of SIS.}

As explained by Malerba $(2002,2005)$, a sectoral innovation system, as well as the sectorial dynamics, is given by the degree of interaction between the analyzed dimensions, thus, testing the hypothesis of a real association between these analytical dimensions and on what extent are they consistent with the perception of the research agents.

As mentioned, for this analysis we used two non-parametric statistical techniques. The first to be analyzed is the Kendall coefficient $\tau$, which verifies the degree of association or cor-

\begin{tabular}{|l|l|l|l|l|l|}
\hline & TEC & ORG & INST & & \\
\hline Kendall's tau_b & TEC & Correlation Coefficient & I,000 & $0,632^{* *}$ & $0,423^{*}$ \\
\hline & & Sig. (2-tailed) &. & 0,001 & 0,028 \\
\hline & ORG & Correlation Coefficient & $0,632^{* *}$ & $\mathrm{I}, 000$ & $0,427^{*}$ \\
\hline & & Sig. (2-tailed) & $0,00 \mathrm{I}$ &. & 0,028 \\
\hline & INST & Correlation Coefficient & $0,423^{*}$ & $0,427^{*}$ & $\mathrm{I}, 000$ \\
\hline & & Sig. (2-tailed) & 0,028 & 0,028 &. \\
\hline
\end{tabular}

Table 5 Kendall Concordance Coefficient $\tau$. Source: Research data

** Correlation is significant at the 0.01 level (two-tailed) * Correlation is significant at the 0.05 level (two-tailed) Notes to $\mathrm{N}=16$

\begin{tabular}{|l|l|l|l|l|l|}
\hline & TEC & ORG & INST & & \\
\hline Spearman's rho & INTERORG & Correlation Coefficient & $0,776^{* *}$ & $0,648^{* *}$ & 0,406 \\
\hline & & Sig. (2-tailed) & 0,000 & 0,007 & 0,119 \\
\hline & COOPCONC & Correlation Coefficient & 0,125 & 0,283 & $-0,175$ \\
\hline & & Sig. (2-tailed) & 0,644 & 0,288 & 0,517 \\
\hline & INTERFOR & Correlation Coefficient & 0,195 & 0,160 & 0,126 \\
\hline & & Sig. (2-tailed) & 0,469 & 0,555 & 0,641 \\
\hline
\end{tabular}

Table 6 Correlation Coefficient $\rho$ of Spearman. Source: Research data

** Correlation is significant at the 0.01 level (two-tailed) * Correlation is significant at the 0.05 level (two-tailed)

Notes to $\mathrm{N}=16$

ISSN: 07I 8-2724. (http://www.jotmi.org)

Journal of Technology Management \& Innovation (c) Universidad Alberto Hurtado, Facultad de Economía y Negocios. 
relation between a set of three or more variables (Siegel, 1975). Yet according to the author, the test result is between

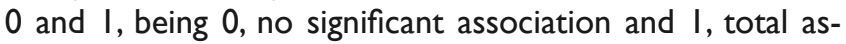
sociation. Therefore, for this study, the favorable results are those that are positioned closer to the unit.

In this test (Table 5), the null hypothesis was defined as: the proxy variables representing the analysis dimensions of a sectoral innovation system (Technologies - TEC Organizations - ORG, and Institutions - INST) are not associated with each other.

The results are shown in Table 5. It is possible to observe that the coefficients are significant and that the association between organizations and technology is close to the unit (0.632), which may be suggestion a large variation in the responses about the relations between firms and public agencies, customers, suppliers and universities. However, the results as well indicate, that there is a strong association between the SIS dimensions of sugarcane sector, according to what is stated by Malerba (2002), the sectoral system elements are correlated, which means that they are mutually dependent.

This high level of variables association indicates the existence of a mutual interaction, in the sense that a system is formed in the studied industry.

Following the concordance analysis, the present research conducted tests in order to check the relationship intensity between the variables that describe the dimensions of the sectoral innovation system and the variables which define the interactions between firms and researched: a) the general organizations of SIS (InterOrg), b) the cooperation with competitors (COOPCONC) and c) the suppliers (Interfor). The relationship intensity was measured by two nonparametric correlation tests. The choice of both tests is due to the advantage they present by not being dependent on assumptions of normality and homoscedasticity, which are required for the performance of parametric correlation tests. The non-parametric correlated to $\rho$-test of Spearman is robust with respect to the sample size, as the test ability is not limited to small samples (Pestana; Gageiro, 2000, p. I45).

By analyzing the results in Table 6, we note that the significant correlations are only appearing among three variables. There is an association between the interaction proxy among sector organizations and the studied firms (InterOrg), and the proxies of the dimension technology (TEC) and the dimension organizations (ORG). This result allows us to infer that the relationship with the organizations - represented by InterOrg and ORG, has influenced the changes in perception about technology, namely, processes as: development, transfer and the use of technologies in the industry, are also related to the nature of relations between organizations. Ultimately, the way in which these relationships occur, that may also be regarded as institutions, determines the sector dynamics, as recommended by Malerba (2005, p. 396).

To Sum up, both statistical methods confirmed the existence of all the elements of a Sectoral Innovation System.

\section{Conclusions and Recommendations}

This research main goal was to examine the interactions between firms from the sugar-energy industry of Alagoas observing three dimensions (organizations, institutions and technologies) of a Sectoral Innovation System as proposed by Malerba $(2002,2005)$.

In General, the tests confirmed the proposed hypothesis, that there is an association between the dimensions foreseen by the author, and that those dimensions develop mutual complementarities, means, they constitute systemic interactions, especially displayed in tables 4 and 6 .

On the other hand, the interactions between agents and other organizations, suppliers and competitors were stable; in other words, the responses in average were not much disparate from the value of 3.This may be reflecting the current situation of sugarcane agroindustry in Alagoas, since, due to market guarantees, as the U.S. quota, and the characteristics of local production, the state firms may not be mobilizing by virtue of the recent changes in the industry.

A relevant point to emphasize and which may poses new research, is a cooperative relationship between the respondent firms (which were practically all the firms in Alagoas, knowing that 8 of these firms are members of groups with more than one plant in the state) and between their suppliers in several situations. This finding is relevant, since there are groups of mutual exchanges of knowledge and technology throughout the industry sector as the Group of Sugar and Ethanol Technological Areas (GATUA) and the Study Group of Human Resources in Sugarcane Agroindustry (GERHAI). From the specific objectives point of view, the survey revealed that the sugarcane agroindustry in the state of Alagoas presents a tradition of R\&D investments, which is marked by a network of research in partnership with RIDESA and other organizations inserted in the system, among them, universities, associations, syndicates, financial and support agencies, sectoral innovation system members, described in Sections 4.1 and 4.2 .

The analysis results demonstrated that investments in innovation are more intense regarding the development of genetic variation for sugarcane production, reaching a threshold of $10 \%$ on the volume of firms' sales. For the most part,

ISSN: 07 I8-2724. (http://www.jotmi.org)

Journal of Technology Management \& Innovation (c) Universidad Alberto Hurtado, Facultad de Economía y Negocios. 
these investments are directed to the agricultural area of the firm, such as the developments of new varieties of plant/ seed which are resistant to pests and disease, agricultural planting techniques, and irrigation and soil management.

At last, the research provides a contribution by conducting an analysis that allows us to verify, in a more regional aggregation level, the existence of constituent elements of a Sectoral Innovation System (SSI), which in the case of sugarcane agroindustry, shows some characteristics of international interactions, according to Fonseca; Rosary (2007).

An abstract element, but important in a research with SIS is the understanding of coevolution of agents/organizations, institutions and technologies. This research sheds some light in that direction, showing that the interactions between agents are a result of reliance on this industry path established by PROÁLCOOL, yet 1975. However although this was not the main purpose of the research, it is worth the leave a note regarding the importance of understanding the coevolution phenomenon in order to complement and enrich the analysis of sectorial systems.

Particularly, the sector may benefit from the analysis done in this work, since it presents information and discussions which, on the one hand, help to assess the ongoing changes and on the other, points for a significant impact of the practices which are associated with the existence of Sectoral Innovation System. Among the limitations of this study, we can highlight the verification of relations by the use of correlation coefficients, since, regarding the sample size, it is recommended, to expand the study, with a longitudinal analysis, in order to examine the coevolution process by an increased sample, using a larger number of firms.

\section{References}

AGROLINK (20I0). Ridesa libera I 3 novas variedades de cana RB em Alagoas. Recovered: <http://www.agrolink. com.br/noticias/NoticiaDetalhe.aspx? codNoticia= I | 0548>. Acess: 20 December 2010.

ALVARENGA, R. P. \& Queiroz, T. R. (2009). Produção mais limpa e aspectos ambientais na indústria sucroalcooleira. International Workshop Advances in Cleaner Production. Recovered em: <http://www.advancesincleanerproduction. net/second/files/sessoes/4a/3/T.\%20R.\%20Queiroz\%20-\%20 Resumo\%20Exp.pdf>.Acess: I 2 February $201 \mathrm{I}$.

ANDRADE, M. C. (200I). Espaço e tempo na agroindústria canavieira de Pernambuco. Estudos Avançados, vol. 15, n. 43, pp. 267-280. Recovered: <http://dx.doi.org//0.1590/S0I0340142001000300020>. Acess: I 2 February 20II.

BARBOSA, G. (2007). Tendência do melhoramento genético da cana-de-açúcar. In: Simpósio da agroindústria da cana-deaçúcar de alagoas, 24, 2007, Maceió. Slides. Maceió: Ridesa, Pp. I-80.

BELL, M. \& Albu, M. (1999). Knowledge Systems and Technological Dynamism in Industrial Clusters in Developing Countries. University of Sussex, Brighton, UK. World Development. vol. 27, n. 9, pp. I7I5-I734.

BELIK,V. \& Vian, E. F. (2002). Desregulamentação estatal e novas estratégias competitivas da agroindústria canavieira em São Paulo. In: Moraes, M.A. F. D. \& Shikida, P. F.A.Agroindústria Canavieira no Brasil. São Paulo:Atlas.

BRESCHI, S. \& Malerba, F. (1997). Sectoral Innovation Systems. In: Edquist, C. Systems of Innovation: technologies, institutions and organization. Londres: Pinter.

CARVALHO, C. P. de O. (200I). Análise da reestruturação produtiva da agroindústria sucro-alcooleira alagoana (2nd ed.) Maceió: EDUFAL.

COOKE, P. (200I). Regional innovation systems, clusters, and the knowledge economy. Industrial and Corporate Change, vol. I0, n. 4, pp. 945-974.

EDQUIST, C. (2005). Systems of Innovations. In: Fagerberg, J., Mowery, D. C. \& Nelson, R. R. The Oxford handbook of innovation. Oxford: Oxford University Press.

FERRAZ, J. C., Kupfer, D. \& lootty, M. (2003). Made in Brazil: Industrial Competitiveness IO Years after Economic Liberalisation. Latin America Studies Series n. 4. Japan External Trade Organization.

ISSN: 07 I 8-2724. (http://www.jotmi.org) 
FERNANDES,A. C. (2003). Cálculos na Agroindústria da Cana-de-açúcar (2nd ed.). Sociedade dos Técnicos Açucareiros e Alcooleiros do Brasil. Piracicaba.

FIEA. (2007). Relatório de Pesquisa de Desempenho Industrial.

(2010). Relatório de Competitividade.

FONSECA, M. D. \& Rosario, F. J. P. (2007). Mudanças nos padrões competitivos da indústria de açúcar e álcool no Brasil: implicações dinâmicas frente aos desafios globais e mudanças tecnológicas. In ALTEC (org.), Anais, Seminário LatinoIberoamericano de Gestion Tecnologica (pp. I-1235). Buenos Aires:Altec, 2007. pp. I-I235. CD-ROM.

FONSECA, M. D., Silveira, J. M. J., Rosário, F. J. P., Mernard, C., \& Ely, R. N. (2007) Sistemas setoriais de inovação: agroindústria de grãos e de cana-de-açúcar. Rio de Janeiro. Seminário Globelics, April.

FRANCO, L. (20I I). Gestão Familiar. Revista Globo Rural, Rio de Janeiro: Globo, ano 26, n. 304.

HANDBOOK of Biological Statistics. Recovered: <http:// udel.edu/ mcdonald/statspearman.html>. Acess: 03 April 2011.

IEL/NC \& SEBRAE. (2005). O novo ciclo da cana: estudo sobre a competitividade do sistema agroindustrial da canade-açúcar e prospecção de novos empreendimentos. Brasília. Instituto Evaldo Lodi e Serviço Brasileiro de Apoio as Pequenas e Médias Empresas.

IPEADATA (Comp.). Banco de Dados:ANFAVEA. Recovered: <www.ipeadata.gov.br/>.Acess: 25 January 201 I.

MALERBA, F. (2002). Sectoral system of innovation and production. Research Policy, n. 3 I, pp. 247-264.

MALERBA, F. (2005) Sectoral Systems: How and why innovation differs across sectors. In: Fagerberg, J., Mowery, D. C. \& Nelson, R. R. (2005). The Oxford handbook of innovation. Oxford: Oxford University Press. Cap. I4, pp. 380-406.

MAPA - Ministério da Agricultura, Pecuária e Abastecimento. Recovered: <http://extranet.agricultura.gov.br/php/ proton/cultivarweb/cultivares_registradas.php>. Acess: 28 October 2011.

PAVITT, K. (1984) Sectoral patterns of technical change:Towards a taxonomy and a theory. Science Policy Research Unit, vol. 13, n. 06.
PINSONNEAULT, A. \& Kraemer, K. (1993). Survey research in management information systems: an assessement. Journal of MIS, vol. I0, n. 2, pp. 75-I05.

PROCANA (2010). Usinas do Nordeste se "nacionalizam". Recovered: <http://www.jornalcana.com.br/conteudo/noticia.asp?id_materia=2389 I $>$.Acess: I5 February $201 \mathrm{I}$.

RAMOS, P. (2002). Heterogeneidade e integração produtiva na evolução recente da agroindústria canavieira do centrosul. In: Moraes, M.A. F. D. \& Shikida, P. F. A. Agroindústria Canavieira no Brasil. São Paulo:Atlas.

ROSÁRIO, F. J. P. (2008). Competitividade e Transformações Estruturais na Agroindústria Sucroalcooleira no Brasil: uma análise sob a ótica dos sistemas setoriais de inovações. Doctoral Thesis, Universidade Federal do Rio de Janeiro, Rio de Janeiro.

UDOP (2009). Ranking de produção por grupos Safra 2007/2008. RIDESA. Catálogo Nacional de Variedades RB. Recovered: <http://www.udop.com.br/download/estatistica/ ranking_producao/ranking_grupos_08.pd>.Acess: 23 March 2011 .

SIEGEL, S. (1975). Estatística não-paramétrica. São Paulo: McGraw-Hill.

SZMRECSANYI, T. \& Moreira, E. P. (199I). O desenvolvimento da agroindústria canavieira do Brasil desde a Segunda Guerra Mundial. Estudos Avançados, vol. 5, n. II, Pp. 57-79. Recovered: <http://dx.doi.org//0.1590/S0I0340141991000100006>. Acess: 02 February 2012.

VIAN,A. C. F. (2002). Inércia e mudança institucional: estratégias competitivas do complexo canavieiro no Centro-Sul do Brasil. Doctoral Thesis. Universidade Estadual de Campinas, Campinas.

WAACK, R. S. \& Neves, M. F. (1998). Competitividade do sistema agroindustrial da cana-de-açucar. São Paulo: IPEA. Recovered: <http://www.agencia.cnptia.embrapa.br/Repositorio/Vol_V_CANApartel_000fxg2yfra02wyiv80soht9hnd dhjbd.pdf $>$.Acess: 25 February $201 \mathrm{l}$. 
NOTES

Particularly the Eastern European and Asian countries that have experienced an increase in income over the decade of the 1990s (Waak \& Neves, 1998).

A good example was the structuring of Brazil Alcohol and the Brazilian Alcohol stock market (BBA). Both were created between 1997 and 1998 and targeted to the producers in the Center-South (CS). The creation of these organizations had the goal to increase alcohol prices (Vian, 2002).

The content of total reducing sugars is an important knowledge required in order to evaluate the quality of the raw material, particularly those intended for the production of alcohol (ethanol). In sugar mills and alcohol that is the parameter used to evaluate the industrial process and to balance the lose of sugars in various manufacture stages of these products (Fernandes, 2003).

In 1987 crisis began in the distribution of alcohol fuels, since Petrobras had problems in alcohol-accounts together with the decline in international oil prices, resulting in a reduced effort of ethanol production in Brazil.

Pinsonneault \& Kraemer (1993) define survey research as a way to collect data or information about particularities of a group, through the questionnaire instrument.

The minimum efficient scale is the production scale in which the average unit costs stop decreasing, that is, the region in which the firms operate in their lower costs, given the market size. Here it is calculated by the median production in the plants of Alagoas.

The idea of clean technologies stems from the concept of a management model for a cleaner production (CP), which acts preventively and is applicable to processes, products and services. This of argument also holds that the generation of residues is a waste and a cost to the business. These clean technologies involve: machines that prevent sugarcane burning, power generation capacity from bagasse, among others. (Alvarenga \& Queiroz, 2009)

DEDINI is the largest company in the Brazilian metalmechanic sector shot can provide all the solutions for the production of sugarcane. Therefore, its greatest asset is the ability to relate with plants which supply equipment, to the extent of being able to deliver a plant, totally assembled and adapted to the situation of soil and climate.

ISSN: 07 I8-2724. (http://www.jotmi.org) 